\author{
RENATA RASZEWSKA-SKAŁECKA \\ Uniwersytet Wrocławski
}

DOI: $10.19195 / 0137-1134.105 .9$

\title{
EDUKACJA OSÓB NIEPEŁNOSPRAWNYCH JAKO DOBRO WSPÓLNE NA TLE ROZWAŻAŃ ADMINISTRACYJNOPRAWNYCH
}

\author{
WPROWADZENIE DO ANALIZY \\ PROBLEMU NIEPEŁNOSPRAWNOŚCI
}

Respektowanie prawa do nauki dzieci i młodzieży z niepełnosprawnością i ich prawa w edukacji ciągle pozostaje problemem przestrzegania ich we współczesnej edukacji, chociaż obecny status osób niepełnosprawnych w ustawodawstwie polskim $\mathrm{i}$ ich sytuacja w państwie się zmienia ${ }^{1}$. Osoby niepełnosprawne żyją wśród nas i uczestniczą w codziennym życiu w społeczeństwie². Coraz częściej

1 W literaturze na temat uprawnień i obowiązków kształtujących status osoby niepełnosprawnej z odpowiednim uwzględnieniem zadań organów administracji publicznej w ujęciu normatywnym, doktryny i judykatury zob. I. Sierpowska, A. Kogut, Status osoby niepetnosprawnej w polskim systemie prawa, Wrocław 2010.

2 Zob. R. Machalska, Społeczeństwo wobec Innego - niepetnosprawnego dziecka, [w:] Społeczeństwo wobec Innego. Kategoria Innego w naukach społecznych $i$ życiu publicznym, red. L. Dziewięcka-Bokun, A. Śledzińska-Simon, Toruń 2010, s. 172-182. Zdaniem R. Machalskiej „Spotykanie w codziennych, naturalnych warunkach osób »o odmiennych właściwościach « staje się właśnie okazją do kształtowania doświadczeń życia w zróżnicowanym społeczeństwie i otwartości na odmienność drugiego człowieka. [...] brak tolerancji jest immanentną cechą człowieka, właściwą naszemu gatunkowi. [...] Aby zlikwidować stygmatyzację osób z różnymi ograniczeniami, nietolerancję odmienności oraz brak racjonalnej oceny możliwości tych osób, potrzebna jest zmiana stosunku osób zdrowych do niepełnosprawnych. Działania integracyjne są próbą stworzenia pomostu łączącego pełnosprawnych z niepełnosprawnymi; [...] uświadomienie ludziom odwiecznego faktu, że zawsze były, są i będą osoby, które nie różnią się od nich niczym prócz stopnia samodzielności w wykonywaniu codziennych czynności”, ibidem, s. 182; por. I. Rudek, Od niechęci do akceptacji. O wychowaniu dzieci do tolerancji wobec osób niepetnosprawnych, Kraków 2008, s. 81-82. Według I. Rudek: „Stosunek społeczeństwa do jednostek odchylonych w jakimkolwiek zakresie od normy staje się we współczesnym świecie wyznacznikiem wartościującym humanizm danego społeczeństwa”, ibidem, cyt. za: R. Machalska, op. cit., s. 182. 
zauważa się w państwie i w życiu publicznym, że osoby niepełnosprawne traktowane są jako „pełnoprawni obywatele i wartościowi członkowie społeczeństwa, a ich postawa oraz życiowa zaradność nierzadko spotyka się z uznaniem i podziwem. Osoby takie uczą się, studiują, odnoszą sukcesy zawodowe, naukowe, sportowe, angażują się w życie polityczne i kulturalne, aktywnie wspierają organizacje społeczeństwa obywatelskiego"3. Trzeba jednak wyraźnie zaznaczyć, że osoby te, ze względu na swe fizyczne lub psychiczne ograniczenia, nie mogą, w ocenie I. Sierpowskiej, swobodnie oraz z zachowaniem pełnej równości, korzystać z praw przysługujących każdemu człowiekowi. Zdaniem autorki: ,żeby urzeczywistnić zasady równości i sprawiedliwości społecznej, osoby te powinny zostać objęte dodatkowymi przywilejami oraz szczególną pomocą władz publicznych"4 — co powinno mieć przełożenie m.in. w procesie wyrównywania szans w rozwoju i egzystencji osób z niepełnosprawnością w życiu publicznym, poprzez udział osób niepełnosprawnych w procesie edukacji, o czym mowa w niniejszym opracowaniu. $Z$ pewnością obszarem wyrównywaniem szans, w tym szans edukacyjnych osób niepełnosprawnych, jest system oświaty i edukacja dzieci i młodzieży z niepełnosprawnością. To tu od najmłodszych lat odbywa się edukowanie i integracja osób niepełnosprawnych ze sprawnymi rówieśnikami, poprzez zapewnienie im w prawie oświatowym i stworzenie w systemie oświaty odpowiednich warunków i organizacji procesu kształcenia, wychowania i opieki. „Idea integracji, czyli ich pełnego włączenia w życie społeczne, wymaga zmiany postaw negatywnych na pozytywne: tolerancji, akceptacji, współdziałania"5. W ramach polityki edukacyjnej państwo winno zapewnić i wprowadzić w życie odpowiednie programy edukacyjne, mające na celu uświadomienie społeczeństwu, zwłaszcza temu najmłodszemu w szkołach i placówkach oświatowych, że osoby niepełnosprawne są wśród nas i są „mimo swoich ograniczeń, osobami rozumnymi”6. W naukach społecznych R. Machalska zauważa, że: „Stereotypy i uprzedzenia, które funkcjonują w [...] społeczeństwie na temat osób niepełnosprawnych, są główną przyczyną trudności w ich pełnej rewalidacji i rehabilitacji"”. Jak konstatuje D. Gorajewska:

społeczeństwo wciąż niewiele wie na temat niepełnosprawności. Rodziny nie są na nią przygotowane. Niegotowe są również szkoły. Paradoksalnie, od rodzin i szkół oczekuje się tego, że przygotują dziecko do godnego życia z niepełnosprawnością i akceptacji niepełnosprawności u innych. Jak zrozumieć, że potrzeby ludzi z niepełnosprawnością nie różnią się od potrzeb osób pełnosprawnych? W poznawaniu problematyki niepełnosprawności ważne jest podjęcie trudu zmiany myślenia i zachowań, czyli łamanie stereotypów ${ }^{8}$.

${ }^{3}$ I. Sierpowska, A. Kogut, op. cit., s. 11.

4 Ibidem, s. 11.

5 I. Krasiejko, Tolerancja wobec osób niepetnosprawnych, „Edukacja i Dialog” 2000, nr 8 (121), s. 3.

6 Por. R. Machalska, Spoteczeństwo wobec Innego..., s. 179.

7 R. Machalska, op. cit., s. 179.

8 Wsparcie dziecka z niepetnosprawnościa w rodzinie i szkole, red. D. Gorajewska, Warszawa 2008, s. 10 (www.integracja.org). 


\section{Zdaniem L. Dziewięckiej-Bokun:}

Ze swej istoty Inność jest wartością. Jest wartością rozwojową, poznawczą, kulturową, estetyczną, religijną, psychologiczną. [...] Inność jest wszechobecna. Teoretycznie jej doświadczanie powinno nas rozwijać, wzbogacać... W praktyce bywa różnie, bowiem Inność może też piętnować, stygmatyzować, marginalizować, wyrzucić poza główny nurt życia społecznego Innych — jednostki, rodziny, grupy społeczne [...]. Postrzegani jako Inni są [...] niepełnosprawni ${ }^{9}$.

\section{Trzeba mieć na uwadze, jak podkreśla autorka, że:}

Inność była zawsze i jest aktualnie dla człowieka wyzwaniem. W XXI wieku problematyka ta zdaje się coraz dotkliwiej obecna w życiu codziennym, a przez utrwalające się procesy wykluczenia społecznego stopniowo nabiera znaczenia politycznego. [...] Jako zjawisko wielowymiarowe ekskluzja społeczna odnosi się do utrwalonych w czasie sytuacji nierównego dostępu do praw i instytucji oraz do drastycznego załamania się stosunków społecznych. [...] Bycie Innym [...] często prowadzi do obiektywnej niemożności korzystania z praw i urządzeń systemowych danej społeczności, dostęp do których formalnie gwarantowany jest wszystkim i każdemu. Znaczy to, że jednostkowa bądź grupowa odmienność powodująca jakiś rodzaj izolacji bądź stygmatyzacji czy wręcz marginalizacji stwarza potencjalną możliwość generowania procesu ekskluzji ${ }^{10}$.

Przypomnijmy na marginesie, że ekskluzja oznacza usunięcie, wyłączenie, wykluczenie. Obejmuje ona:

obok materialnej także i niematerialną deprywację. [...] to wykluczenie z miejsca i relacji w społeczeństwie. [...] We współczesnych społeczeństwach dostępność do różnorodnych systemów funkcjonalnych decyduje o miejscu jednostki czy grupy w systemie społecznym. Porządek [...] systemów społecznych określają reguły dostępności ${ }^{11}$.

Wypada zgodzić się z L. Dziewięcką-Bokun, że ekskluzję w sferze systemów prawa powoduje m.in. samo prawo. Sytuacja taka wynikać może z niskiego poziomu świadomości prawnej oraz słabej informacji na temat obowiązujących rozwiązań prawnych. A ta z kolei przyczynia się do tego, że ludzie niewiele wiedzą o przysługujących im prawach i zabezpieczeniach ${ }^{12}$. Przyczyną ekskluzji może być m.in. niepełnosprawność. W rozwoju każdego kraju niezwykle ważną rolę pełni wykształcenie obywateli. Edukacja i polityka społeczna zajmują się działalnością, których zadania obejmują wyrównywanie szans edukacyjnych ludzi na różnych etapach ich rozwoju. Jak pisze J. Auleytner: „Brak powszechności i równości dostępu do szkół rodzi kwestię edukacyjną. Rozumie się ją jako nierówność ograniczającą z jednej strony szanse jednostki, z drugiej komplikując rozwój społeczno-gospodarczy"13.

Sytuacja prawna obywatela, będącego osobą niepełnosprawną

${ }^{9}$ L. Dziewięcka-Bokun, Inny poza systemem społecznym, czyli o przyczynach ekskluzji spotecznej, [w:] Spoleczeństwo wobec Innego.... s. 380-381.

10 L. Dziewięcka-Bokun, Inny poza systemem społecznym..., s. 382-383; eadem, Ekskluzja społeczna jako problem polityki spolecznej, [w:] Polityka spoleczna. Teksty źródtowe, wyb. i oprac.

L. Dziewięcka-Bokun, K. Zamorska, Wrocław 2003, s. 207-215.

11 L. Dziewięcka-Bokun, Ekskluzja społeczna..., s. 212.

12 Ibidem, s. 215.

13 J. Auleytner, Kwestia edukacyjna, [w:] Polityka społeczna..., s. 333. 
podlega szczególnej regulacji ustawowej i konstytucyjnej, uzasadnionej tym, że poza specjalnymi potrzebami wynikającymi np. z rodzaju choroby, z jaką przyszło mu się zmagać, ma on takie same potrzeby, jak pozostali obywatele i korzysta z takiej samej gwarancji prawnej w zakresie zaspokajania tych potrzeb. Powszechne prawa i wolności obywatela podlegają dodatkowemu wzmocnieniu, szczególnej gwarancji prawnej, nakładającej na organy administracji specjalne obowiązki związane z zapewnieniem osobom niepełnosprawnym możliwości uczestniczenia w życiu społecznym i realizacji praw podmiotowych ${ }^{14}$.

To też oznacza, że

wśród regulacji konstytucyjnych oddziałujących w sferze znoszenia skutków społecznej Inności osób niepełnosprawnych dwie najistotniejsze, to zasada równości wobec prawa [...] art. 32 Konstytucji oraz wyrażający z art. 69 Konstytucji obowiązek pomocy osobom niepełnosprawnym nałożony na władze publiczne ${ }^{15}$.

W społeczeństwie obywatelskim coraz częściej propaguje się wiedzę i zaangażowanie w działalność organizacji pozarządowych na rzecz osób niepełnosprawnych, jesteśmy też uczestnikami różnych działań organizacji pozarządowych mających oddźwięk społeczny, co prognozuje też zmianę postaw jednostki w kierunku pomocy, tolerancji czy współdziałania wobec Inności. Ale czy rzeczywiście jesteśmy jako jednostka, czy społeczność lokalna oraz społeczność szkolna jest w stanie zaakceptować odmienności Innych, z czego może wynikać albo wynika obawa czy lęk wobec Inności, uprzedzenia czy marginalizowanie wobec Inności? Jakie są przyczyny ograniczonego udziału tych osób w życiu publicznym; czy nie jest tak, że w praktyce bywa różnie, że życie czasami weryfikuje nawet najpiękniejsze idee i wartości człowieczeństwa? Stąd też istnieje ciągła potrzeba wiedzy i edukowania jednostki/obywatela co do znajomości sytuacji prawnej osób niepełnosprawnych w społeczeństwie, odwoływania się do obowiązującego w tym zakresie ustawodawstwa określającego podmiotowość prawną osoby niepełnosprawnej, praw dziecka i wartości społecznych w życiu publicznym ${ }^{16}$. Na uwagę zasługuje również argumentacja Jana Pawła II, który pisał: „,Osoby niepełnosprawne w pełni są podmiotami ludzkimi z należnymi im wrodzonymi, świętymi i nienaruszonymi prawami, które pomimo ograniczeń i cierpień wpisanych w ich ciało i władze, stanowią jednak o szczególnym znaczeniu godności i wielkości Człowieka"17. Warto tu dodać, że „dzięki różnym udogodnieniom grupy zagrożone społeczną alienacją mogą funkcjonować w społeczeństwie na równi z pozostałymi jej członkami. [...] ustawodawca stworzył katalog różnorodnych uprawnień, które składają się na status osoby niepełnosprawnej w polskim systemie prawa"18.

${ }^{14}$ M. Tabernacka, Niepetnosprawność a polityka przestrzenna w świetle zasady proporcjonalności, [w:] Spoleczeństwo wobec Innego..., s. 312-313.

15 Ibidem, s. 313.

16 Zob. Spoleczeństwo wobec Innego. Kategoria Innego...; Wartości społeczne w stużbie publicznej, red. L. Dziewięcka-Bokun, J. Kędzior, Toruń 2009.

17 Jan Paweł II, Encyklika Laborem exercens, [w:] Jan Paweł II, Encykliki Ojca Świętego Jana Pawła II, Kraków 2003, s. 144-210, za: R. Machalska, op. cit., s. 182.

18 I. Sierpowska, A. Kogut, op. cit., s. 11-12. 
Z punktu widzenia nauki prawa, prawa dziecka są jednym z typów praw człowieka ${ }^{19}$, zaś Konwencja o prawach dziecka, przyjęta przez Zgromadzenie Ogólne Narodów Zjednoczonych dnia 20 listopada 1989 roku $^{20}$, jest jednym z instrumentów międzynarodowej ochrony praw człowieka ${ }^{21}$. W Konwencji o prawach dziecka nastąpiło uznanie podmiotowości prawnej dziecka oraz sformułowanie katalogu należnych mu praw i jej ochrony ${ }^{22}$. Według M. Piechowiaka:

dziecko jest pełnym podmiotem praw człowieka, nie jest tak, że ma te prawa częściowo, nie w pełni itp., że pełnym podmiotem stanie się dopiero w wieku dorosłym, po osiągnięciu odpowiednich zdolności, możliwości; jego pełnym prawem człowieka jest to, co jest dla niego dobrem, dobrem dla dziecka. [...] mniejszy stopień rozwoju, bycie słabszym, czy niepełnosprawnym, nie jest powodem ograniczania ochrony, ale przeciwnie, jest racją szczególnej, pełniejszej ochrony tych praw, dyktowanej szczególną troską o dziecko i wynikającej z niej szczególnej opieki nad dzieckiem²3.

Dobrze pojęte prawa dziecka w ocenie M. Piechowiaka „charakteryzowane są także przez obowiązki i prawa innych, w tym prawa rodziców i rodziny. Realizacja przynajmniej niektórych dóbr jest dla podmiotu praw także obowiązkiem, jak to jest w przypadku prawa do nauki”24.

W dyskursie nauk pedagogicznych M. Kozak, posługując się ,kategorią praw dziecka", rozumie przez nią

prawo podmiotowe przysługujące $\mathrm{z}$ tytułu prawa naturalnego każdemu człowiekowi w specyficznym okresie jego życia nazwanym dzieciństwem. [...] prawa dziecka są integralną częścią, a zarazem pochodną praw człowieka. Zostały z nich wyodrębnione i rozwinięte, [...] jako uzupełniające ich brzmienie przez zwrócenie uwagi na konieczność zabezpieczenia przestrzeni dzieciństwa, w której funkcjonuje człowiek ${ }^{25}$.

19 Najogólniej prawa człowieka określa się jako „prawa przysługujące człowiekowi jedynie dlatego, że jest on człowiekiem; ich podmiotem jest każdy człowiek, niezależnie od jego cech i zdolności — jest nim dziecko, jak i niedołężny starzec lub osoba chora i niepełnosprawna. [...] przysługują one niezależnie od aktów prawa stanowionego i — szerzej — niezależnie od wszelkich działań ludzkich, decyzji, głosowań itp., choć od takich decyzji może zależeć, oczywiście, kształt i skuteczność ochrony tych praw. [...] mam prawo z tytułu praw człowieka, to nic innego jak pewne podstawowe dobra, niezbędne do życia i prawidłowego rozwoju" — M. Piechowiak, Czym sa prawa dziecka?, [w:] Prawa dziecka po przystapieniu do Unii Europejskiej. Materiaty z konferencji Rzecznika Praw Dziecka, red. M. Potapowicz, M. Krauzowicz, P. Przybylski, Warszawa 2004, s. 15; por. Konwencja o prawach dziecka. Analiza i wykładnia, red. T. Smyczyński, Poznań 1999; M. Jabłoński, S. Jarosz-Żukowska, Prawa czlowieka i systemy ich ochrony. Zarys wykładu, Wrocław 2005; Prawa czlowieka. Wybrane zagadnienia i problemy, red. L. Koba, W. Wacławczyk, Warszawa 2009; Wolności i prawa jednostki w Konstytucji RP, t. 1. Idee i zasady przewodnie konstytucyjnej regulacji wolności i praw jednostki w RP, red. M. Jabłoński, Warszawa 2010.

20 Dz.U. z 1991 r. Nr 120, poz. 526 ze zm.

21 M. Piechowiak, op. cit., s. 14.

22 Zob. M. Jabłoński, S. Jarosz-Żukowska, Prawa człowieka..., s. 211-214.

23 M. Piechowiak, op. cit., s. 14-15.

24 Ibidem, s. 27-28.

25 M. Kozak, Edukacja na rzecz praw dziecka w szkole wyższej. Zarys dydaktyki szczegółowej, Kraków 2014, s. 19 i cyt. tam literatura. 
Zdaniem autorki ,prawom dziecka można przypisać charakter swoisty względem praw człowieka i traktować je jako [...] zbiór uprawnień dzieci wynikających $\mathrm{z}$ obowiązujących $\mathrm{w}$ danym społeczeństwie praw obywatelskich, ustalających status dziecka w państwie, społeczeństwie i w rodzinie"26. Artykuł 4 Konwencji o prawach dziecka zobowiązuje państwa-strony do podejmowania wszelkich działań ustawodawczo-administracyjnych i innych dla realizacji praw w nim uznanych ${ }^{27}$.

$\mathrm{Na}$ gruncie ustawodawstwa polskiego z konstytucyjnego prawa do nauki wynikają publiczne zadania $\mathrm{w}$ dziedzinie oświaty i wychowania, $\mathrm{w}$ tym objęte kształceniem specjalnym, nałożone na państwo i jego administrację publiczną. Administracyjnoprawny kontekst prowadzonych rozważań w zakresie podmiotowego prawa do nauki ${ }^{28}$, w tym o prawach osób z niepełnosprawnością do nauki, ma przybliżyć podstawy prawne dostępu do edukacji publicznej i warunki umożliwiające proces organizowania kształcenia specjalnego ${ }^{29}$.

\section{EDUKACJA JAKO DOBRO CZŁOWIEKA/JEDNOSTKI I DOBRO WSPÓLNE W SPOŁECZEŃSTWIE}

Prawo jest strukturą dwoistą (pomyślaną i rzeczywistą), ale wzbogaconą o trzeci czynnik, jakim są aksjologicznie podstawowe wartości ludzkie — sprawiedliwość, ład i humanizm, które nie są czymś z zewnętrz prawa, lecz w pewnym sensie trwają, utrzymują się w prawie i dzięki prawu ${ }^{30}$. Z perspektywy aksjologii prawa administracyjnego przyjmuje się, że w prawie tym wprost tkwią różne wartości, na których ono się opiera i z których się wywodzi, przy czym z drugiej strony ono samo przez swoje istnienie i obowiązywanie dostarcza na zewnątrz „swoich”, nowych wartości - samo jest wartością i wartości takie konstruuje ${ }^{31}$. Prawo administracyjne, $\mathrm{w}$ tym prawo oświatowe - stanowi element kultury społecznej, a ta zawsze jest budowana wobec jakichś wartości ${ }^{32}$. Edukacja jest „wartością samoistną, a także instrumentem zmian społecznych rozumienia świata oraz kierowania sobą i uczestnictwa w życiu ludzkich wspólnot”33. Jest ważną dziedzi-

26 Ibidem, s. 19.

27 M. Jabłoński, S. Jarosz-Żukowska, op. cit., s. 214.

28 O prawie do nauki i do zakładania szkół zob. O. Rudak, Prawa do nauki, [w:] Wolności i prawa obywatelskie w Konstytucji RP, red. B. Banaszak, A. Preisner, Warszawa 2002, s. 489-506.

29 Zob. ustawa z dnia 7 września 1991 r. o systemie oświaty (tekst jedn. Dz.U. z 2015 r. poz. 2156 z późn. zm., dalej: u.s.o.), art. $71 b$.

30 F. Longchamps, Z problemów poznania prawa, Wrocław 1968, s. 13.

31 J. Zimmermann, Aksjomaty prawa administracyjnego, Warszawa 2013, s. 73-74.

32 S. Fundowicz, Aksjologia prawa administracyjnego, [w:] Koncepcja systemu prawa administracyjnego, red. J. Zimmermann, Warszawa 2007, s. 633.

33 C. Banach, Skarb ukryty w edukacji. Strategia rozwoju edukacji w Polsce do roku 2020, s. 1, www.up.krakow.pl/konspekt/12/strategia.html, (dostęp: 4 sierpnia 2015); zob. też B. Śliwerski, Edukacja (w)polityce. Polityka (w)edukacji. Inspiracje do badań polityki oświatowej, Kraków 2015. 
ną życia społecznego, służy osiąganiu celów społecznych, realizacji jego potrzeb. Dokonuje się ona w społeczeństwie i skierowana jest ku przyszłości ${ }^{34}$.

Preambuła do ustawy z dnia 7 września 1991 r. o systemie oświaty odwołuje się do celów ustanowienia regulacji prawnej, ze wskazaniem na doniosły charakter oświaty jako jednej z podstawowych potrzeb społecznych, mającej związek z odpowiedzialnością państwa i samorządu terytorialnego za funkcjonowanie całego systemu oświaty, a której szczególnym przejawem jest wymaganie zapewnienia powszechnej dostępności szkół publicznych ${ }^{35}$. Z aksjologicznego punktu widzenia, nie możemy przy ich wykonywaniu pomijać wartości, jakie dotyczą prawa administracyjnego, tkwią w nim lub z niego wynikają ${ }^{36}$; w tym wartości, dotyczących prawa oświatowego i systemu oświaty.

Zgodzić należy się z tezą J. Zimmermanna, że „w demokratycznym państwie prawnym i w jego systemie prawa każda norma, ale i każda instytucja prawna, ma swoje podłoże aksjologiczne. W racjonalnym systemie prawa nie do pomyślenia jest bowiem regulacja nieoparta na żadnych wartościach, a patologią są regulacje przeczące wartościom, zbudowane na swoistych »antywartościach«"37. Prawo, a zwłaszcza

34 Zob. M.J. Szymański, Socjologia edukacji. Zarys problematyki, Kraków 2013; idem, Edukacyjne problemy wspótczesności, Kraków 2014.

35 Zob. M. Pilich, Ustawa o systemie oświaty. Komentarz, Warszawa 2012, s. 25-26.

36 J. Zimmermann, op. cit., s. 75. Zdaniem autora: „Normy prawne powinny mieć swoje uzasadnienie aksjologiczne, powinny być osadzone w wartościach - odnosi się to w całości również do norm prawa administracyjnego. [...] Katalog wartości, na jakich opiera się uzasadnienie aksjologiczne norm, jest różny w każdej dziedzinie prawa. Są to wartości wynikające z danego systemu norm, które dany system nakazuje realizować, albo wartości postulowane wobec danego systemu. Wartości mają służyć temu, co dobre, eliminując wszystko to, co stanowi jego negację. Prawo administracyjne powinno być nastawione na ochronę wartości lub dóbr ważnych w ludzkim współistnieniu", ibidem, s. 74. Z aksjologicznego punktu widzenia, „można mówić o trzech częściach prawa administracyjnego lub o trzech grupach wartości, jakie dotyczą tej gałęzi prawa, tkwią w niej lub z niej wynikają. Część pierwsza to ten zbiór norm lub zbiór postulatów, które wprowadzają lub mogłyby wprowadzać w obręb prawa administracyjnego wartości uniwersalne, czyli wartości leżące poza tym prawem, niezbędne dla jego należytego funkcjonowania. [...] Część druga to wartości niepochodzące i niebrane z zewnątrz, ale tworzone przez samo prawo administracyjne lub też Konstytucję, specjalnie dla jego potrzeb, po to, aby podmioty stosujące to prawo mogły działać w oparciu o trwałe założenie aksjologiczne. Wprowadza się więc daną normę po to, żeby stosowanie innych norm prawa administracyjnego spełniało standardy uważane za pożyteczne zwłaszcza w relacjach administracja publiczna - obywatel. [...] Część trzecia to wartości, które prawo administracyjne specjalnie chroni, czyli takie, dla ochrony których prawo administracyjne jest tworzone. Wprowadza się więc daną normę po to, żeby skonstruować instrument administracyjnoprawny zapobiegający niszczeniu lub podważaniu jakichś wartości lub dóbr", tamże, s. 75-76. Do tej ostatniej grupy wartości należy interes publiczny jako podstawowa wartość chroniona przez prawo administracyjne. Szerzej zob. Wartości w prawie administracyjnym, red. J. Zimmermann, Warszawa 2015.

37 J. Zimmermann, Aksjologiczna ranga samorządowych kolegiów odwoławczych, „Casus” 2015, nr 75, s. 33. Zob. R. Raszewska-Skałecka, Niepewność w oświacie jako antywartość w prawie administracyjnym, [w:] Antywartości w prawie administracyjnym, red. A. Błaś, [w druku]. 
prawo administracyjne ma służyć dobru człowieka, co można uznać za jego podstawową, w istocie jedyną powinność i sens jego istnienia. [...] nie powinno być tworzone dla samego siebie ani dla administracji, która ma za zadanie służyć człowiekowi lub wspólnotom ludzkim. [...] Dobro człowieka (jednostki) łączy się w prawie administracyjnym z dobrem wspólnym [...]. Dobro człowieka będzie więc przełożone na interes indywidualny, a dobro wspólne na interes publiczny. Tam również to ogólne dobro przełoży się na kategorie szczegółowe [...] Dobro człowieka, jako wartość nadrzędna, powinno być zawsze uwzględniane w całym prawie administracyjnym bez względu na jego wewnętrzne podziały ${ }^{38}$.

Prawo administracyjne ma służyć człowiekowi ${ }^{39}$, nie zaś samej administracji, ma służyć obywatelowi i go ochraniać ${ }^{40}$. Według J. Bocia: „,warto podnieść służebną wobec obywateli funkcję administracji" ${ }^{41}$.

Administracja publiczna ,nie ma własnych celów, lecz są one położone w sferze praw i wolności obywateli. Realizuje te cele nie jako własne, lecz dla dobra i na rzecz obywateli. Cele te realizowane są jako zadania publiczne, zrekonstruowane w prawniczych konstrukcjach kompetencji prawnych organów administra-

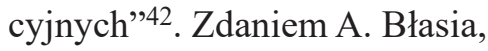

prawo mające znaczenie tylko dla organu administracyjnego, w istocie nie istnieje $\mathrm{i}$ istnieć nie powinno. Zadania administracji, sprawy administracyjne, które administracja załatwia, nie stanowią autonomicznego celu administracji. Zadania administracyjne — szerzej — cała aktywność organów administracyjnych zawsze ma znaczenie dla obywatela. Administracja nie pracuje dla samej siebie. Cała jej aktywność jest podejmowana $\mathrm{w}$ istocie dla zapewnienia bezpieczeństwa zewnętrznego, wewnętrznego i socjalnego obywateli. [...] Aktywność administracyjna organów administracji publicznej podejmowana jest dla urzeczywistnienia praw i wolności człowieka i obywatela. Administracja publiczna - nie ma własnych wolności i praw, a jedynie kompetencje, które umożliwiają jej podejmowanie działalności. Zawsze dla dobra publicznego, nie dla dobra własnego ${ }^{43}$.

Według L. Zacharko „działania administracji publicznej winny być ukierunkowane na zabezpieczenie interesu publicznego i jej celem jest realizacja dobra wspólnego oraz zapewnienie niezbędnego minimum dóbr publicznych i usług publicznych"44. Zdaniem M. Kamińskiego konstrukcja pojęciowa dobra wspólnego jest uznawana za podstawę legitymacyjną państwowości w warunkach ustroju demokratycznego i praworządnego. W tej sytuacji pozwala to na uznanie państwa za

38 J. Zimmermann, Aksjomaty ..., s. 77.

39 Zob. Z. Duniewska, Prawo administracyjne - wprowadzenie, [w:] System Prawa Administracyjnego t. 1. Instytucje prawa administracyjnego, red. R. Hauser, Z. Niewiadomski, A. Wróbel, Warszawa 2010, s. 99.

40 J. Zimmermann, Aksjomaty..., s. 260.

41 J. Boć, Język administracji, [w:] Wspótczesne europejskie problemy prawa administracyjnego i administracji publicznej. W 35. rocznice utworzenia Instytutu Nauk Administracyjnych Uniwersytetu Wrocławskiego, red. A. Błaś, K. Nowacki, „Prawo” CCXCV, 2005, s. 93.

42 A. Błaś, $W$ sprawie jakości działań organów administracji publicznej $w$ demokratycznym państwie prawa, [w:] Jakość administracji publicznej, red. J. Łukasiewicz, Rzeszów 2004, s. 60, 63.

43 Ibidem, s. 63.

${ }^{44}$ L. Zacharko, Refleksja nad kategoria dobra publicznego, [w:] Dobra publiczne w administracji, red. M. Woźniak, E. Pierzchała, Toruń 2014, s. 18. 
instytucjonalne narzędzie realizacji dobra wspólnego oraz za prawnego gwaranta tegoż dobra ${ }^{45}$.

W państwie prawa rolą administracji publicznej jest wykonywanie prawa, a ściślej — określonych prawnie zadań publicznych, będących prawnymi obowiązkami, których za realizację administracja publiczna jest odpowiedzialna ${ }^{46}$. Podkreślmy tu, że każde zadanie publiczne służy realizacji dobra wspólnego, będącego determinantą zasadniczych celów i funkcji państwa ${ }^{47}$. Zdaniem M. Stahl „określenie »zadania publiczne« wiązane jest z celami publicznymi (użyteczności publicznej), jakie ma zrealizować administracja, a z kolei te cele utożsamiane są z interesem publicznym" 48 . Autorka zauważa, że „podstawowym celem władzy publicznej (państwa) jest troska o dobro wspólne, także utożsamiane z kategorią interesu publicznego. Administracja publiczna rozrasta się i staje się »coraz bardziej wpływową instytucją systemu politycznego«, a [...] uwarunkowania wpływają na formułowanie celów publicznych, na treść jej działań, zakres zadań publicznych, formy ich wykonywania oraz wymuszają dostosowywanie się do zmieniających się warunków"49.

Przejęcie odpowiedzialności państwa za realizację zadania w zakresie oświaty i nauki wynika z jego publicznego charakteru ${ }^{50}$, co wynika $z$ art. 70 Konstytucji RP. Cele i zadania polskiego systemu oświaty sformułowane zostały w przepisach ogólnych ustawy o systemie oświaty (art. 1 u.s.o.) ${ }^{51}$. Wskazać należy, że

system oświaty zapewnia w szczególności realizację prawa każdego obywatela Rzeczypospolitej Polskiej do kształcenia się oraz prawa dzieci i młodzieży do wychowania i opieki, odpowiednich do wieku i osiągniętego rozwoju. Konstytucyjne prawo do nauki zostało powiązane z obowiązkiem jej pobierania do 18 roku życia. Zaadresowane do jednostek, ale również do władz publicznych, zobligowanych do podjęcia działań zabezpieczających właściwe korzystanie z tego prawa (zorga-

45 M. Kamiński, Wymiar aksjonormatywny pojęcia dobra wspólnego w prawie administracyjnym, [w:] Dobra publiczne..., s. 25.

46 A. Błaś, Administracja publiczna w państwie prawa, [w:] A. Błaś, J. Boć, J. Jeżewski, Nauka administracji, Wrocław 2013, s. 40-45; idem, Zadania administracji publicznej w państwie prawa, [w:] Nauka administracji..., s. 137.

47 M. Stahl, Cele publiczne i zadania publiczne, [w:] Koncepcja systemu prawa administracyjnego. Zjazd Katedr Prawa Administracyjnego i Postępowania Administracyjnego, red. J. Zimmermann, Warszawa 2007, s. 99. „Ponieważ za cel ostateczny działania administracji uważa się dobro wspólne, a realizacji tego celu może sprzyjać także realizacja celów jednostkowych, to tym samym dobro wspólne, determinując obszar działania administracji, może być traktowane jako dobro wspólne wszystkich obywateli”.

48 Ibidem, s. 95.

49 Ibidem, s. 96-97.

50 Zob. R. Kusiak-Winter, Odpowiedzialność państwa za realizację zadania w zakresie szkolnictwa wyższego - perspektywa historyczna i wspótczesna, „Przegląd Prawa i Administracji”, C/1, 2015, s. 155. Zdaniem autorki: , jego publiczny i niezbywalny charakter wskazuje na państwo jako ostateczną instancję decyzyjną", ibidem, s. 159; por. M. Stahl, op. cit., s. 97. Zdaniem M. Stahl: publiczny to ogólnie, powszechnie dostępny, do powszechnego użytku, to przeciwieństwo prywatnego, to coś przeznaczone do użytku zbiorowego, powszechnego".

51 Tekst jedn. Dz.U. z 2015 r. poz. 2156 z późn. zm. 
nizowanie i utrzymanie odpowiedniej liczby szkół, wyegzekwowanie obowiązku, o którym mowa w art. 70 ust. 1 Konstytucji RP). Intencją prawodawcy było stworzenie modelu prawa do nauki i systemu oświaty przeciwdziałającego dyskryminacji jednostek do wykształcenia $[\ldots]^{52}$.

Wpływ na sposób rozumienia oświaty jako zadania publicznego ${ }^{53}$ wynika z regulacji ustawowej i uznanie jej w preambule do u.s.o. za dobro wspólne całego społeczeństwa. Będąc jego dobrem wspólnym, „wyraża się w kształceniu, wychowaniu i opiece organizowanych w formach realizujących uznane zasady i wartości, na których jest ona zbudowana" 54 . Owo „dobro wspólne” „nie może się oddalać ani nie może być oddalane od obywatela, dla którego potrzeb ostatecznie jest pomyślane. Dobro wspólne ma służyć dobru jednostki, jego tworzeniu, poszerzaniu i pogłębianiu [...]”55. W ocenie J. Bocia: „określone dobro wspólne nie musi dotyczyć wszystkich obywateli, ale też nie może być dzielone i nie może działać wybiórczo. W takim położeniu znajduje się każde dobro, które jest wyodrębnione, nazywane i ma możliwość społecznego odniesienia"56. Przykładem takiego wyodrębnienia, nazwania i społecznego odniesienia jest oświata, mająca cechę dobra w znaczeniu indywidualnym i jednocześnie cechę wspólności, oparta na podstawowych i uniwersalnych wartościach ujętych w Konstytucji RP i w ustawie o systemie oświaty, w tym preambule do u.s.o. Zgodzić należy się z M. Stahl, że „nie ma jednego dobra wspólnego (publicznego), pojęcie to wyraża pewne podstawowe wartości określonej wspólnoty politycznej (wspólnoty europejskiej, państwa, regionu, powiatu, gminy) czy organizacji"57. Podobnie wypowiada się J. Boć, według którego nie można mówić o jednym dobru wspólnym, gdyż sama istota dóbr i ich treść mogą być różne i występować pod wieloma postaciami ${ }^{58}$. Także w ocenie Trybunału Konstytucyjnego nie ma jednego dobra wspólnego, lecz są różne dobra i wartości, które wymagają ochrony i gwarancji w kontekście zasady demokratycznego państwa prawnego urzeczywistniającej

52 Prawo oświatowe, red. S.M. Kwiatkowski, K. Gawroński, Warszawa 2013, s. 33; P. Bała, Konstytucyjne prawo do nauki a polski system oświaty, Warszawa 2009, s. 224-229.

53 Zob. D. Kurzyna-Chmiel, Oświata jako zadanie publiczne, Warszawa 2013. „Szczególny wpływ na ustalenie zakresu pojęcia i sposobu realizacji oświatowych zadań publicznych ma kreowana w danym okresie polityka oświatowa państwa i zmieniający się interes publiczny”, ibidem, s. 16.

54 Ibidem, s. 26.

55 J. Boć, Z refleksji nad dobrem wspólnym, [w:] Nowe problemy badawcze w teorii prawa administracyjnego, red. J. Boć, A. Chajbowicz, Wrocław 2009, s. 152-153. „W ujęciu funkcjonalnym dobro wspólne może występować w trzech podstawowych ujęciach. Po pierwsze, jako idea, która albo wyznacza, albo też kształtuje treść przyszłych zachowań, albo potwierdza zgodność zachowań dotychczasowych z nią samą. Po drugie, dobro wspólne występuje jako motywacja podejmowania określonych działań; w przypadku państwa — działań publicznych, a w przypadku obywateli działań prywatnych o znaczeniu publicznym. [...] w trzecim ujęciu, dobro wspólne ma znaczenie nakazu obowiązującego niezależnie od liczby i rodzaju jego beneficjentów a przymuszającego do nadania określonemu działaniu określonych kształtu i treści”, ibidem, s. 153.

56 Ibidem, s. 153.

57 M. Stahl, op. cit., s. 97.

58 J. Boć, Z refleksji nad dobrem..., s. 152. 
idee sprawiedliwości społecznej59. Oświata postrzegana jest jako dobro człowieka $\mathrm{w}$ kategoriach takich jak czyni m.in. S. Biernat, który dobrami określa wszystko to, co ma dla ludzi wartość, co zaspokaja ludzkie potrzeby, co ludzie cenią i chcą miećc ${ }^{0}$. G. Szpor przyjmuje podobnie, nazywając dobrem „to, co ma dla ludzi wartość, co zaspokaja ludzkie potrzeby, co ludzie cenią i chcą mieć"61. Współcześnie jednostka, a szerzej społeczeństwo, ma potrzebę edukacji i pełną jej świadomość jako wartości.

Zaspokajanie potrzeb w dziedzinie edukacji (potrzeby wiedzy) stanowi ze strony administracji publicznej świadczenie usług ${ }^{62}$. Jak pisze P. Chmielnicki: „Edukacja publiczna polega na ciągłym i nieograniczonym w czasie zaspokajaniu przez administrację publiczną potrzeb w zakresie wiedzy i umiejętności, określonych przez indywidualne cechy ucznia lub wychowanka, za pomocą działalności ludzkiej, której bezpośrednim rezultatem nie jest wytworzenie żadnego dobra materialnego"63. Oświata jest częścią administracji publicznej, ujmuje się ją najczęściej w kategoriach „dobro wspólne”, „dobro publiczne”, a wiedzę postrzega się jako szczególnego rodzaju „dobro niematerialne”, którego brak odczuwany jest negatywnie w rozwoju państwa i społeczeństwa ${ }^{64}$. Prawo administracyjne,

59 D. Kurzyna-Chmiel, op. cit., s. 24-25.

60 S. Biernat, Rozdziat dóbr przez państwo. Uwarunkowania spoteczne i konstrukcje prawne, Wrocław 1989, s. 9; za: P. Chmielnicki, Zakłady administracyjne w Polsce. Ustrój wewnętrzny, Warszawa 2008, s. 26.

${ }^{61}$ G. Szpor, Korzystanie z dóbr publicznych, [w:] Prawo administracyjne. Część materialna, red. Z. Niewiadomski, Warszawa 2004, s. 118.

62 P. Chmielnicki, Świadczenie ustug przez samorząd terytorialny w Polsce. Zagadnienia ustrojowoprawne, Warszawa 2005, s. 42.

63 Ibidem.

${ }^{64}$ Zob. E. Pierzchała, J. Pierzchała, Oświata w sferze ustug publicznych, [w:] Administracja dóbr i ustug publicznych, red. M. Woźniak, Warszawa 2013, s. 112 n. Na temat dobra wspólnego w prawie administracyjnym zob. J. Boć, Z refleksji nad dobrem..., s. 151-154; M. Stahl, Dobro wspólne w prawie administracyjnym, [w:] Nowe problemy badawcze..., s. 47-60; Z. Duniewska, Cel publiczny, interes publiczny i dobro wspólne, [w:] Prawo administracyjne. Pojęcia, instytucje, zasady w teorii $i$ w orzecznictwie, red. M. Stahl, Warszawa 2013, s. 76-80. Zdaniem Z. Duniewskiej, „treść pojęcia dobra wspólnego, jakim jest państwo, jest ogólna, a zarazem szczegółowa, mieszczą się w niej różne elementy nierozerwalnie związane z państwem demokratycznym. Jest to pojęcie otwarte i zmienne w czasie, oparte na podstawowych i uniwersalnych wartościach stanowiących podstawę Konstytucji. W tak rozumianym pojęciu dobra wspólnego mieści się węższa kategoria interesu publicznego", ibidem, s. 78; zob. też Dobra chronione w prawie administracyjnym, red. Z. Duniewska, Łódź 2014. Oświata zaliczana jest do kategorii dóbr publicznych, które nie są łatwe do zdefiniowania. Pojęcie dobra publicznego związane jest z prawem publicznym. Bywa jednak wywodzone z teorii ekonomii. Transpozycja ekonomicznego pojęcia dóbr publicznych, jak pisze J. Supernat, w pojęcie prawne nie jest prosta, ale nie niemożliwa. „Dobra publiczne niekoniecznie są przedmiotami fizycznymi (materialnymi), ale mogą być i są usługami. W takiej sytuacji pojęcie dóbr publicznych koresponduje z prawnym pojęciem usług świadczonych w interesie ogólnym, które mogą być świadczone przez podmioty publiczne i podmioty niepubliczne" — pisze L. Zacharko, op. cit., [w:] Dobra publiczne w administracji, red. M. Woźniak, E. Pierzchała, Toruń 2014, s. 18. Jak konstatuje L. Zacharko, pojęcia ,interes publiczny”, „dobro wspólne”, „,dobro publiczne” są 
a zwłaszcza prawo oświatowe mieszczące się w jego ramach, należy postrzegać z punktu widzenia wartości uniwersalnych, takich jak dobro człowieka, dobro wspólne, sprawiedliwość społeczna, moralność publiczna, a zwłaszcza godność człowieka, która jest źródłem jego wolności i praw ${ }^{65}$. Administracja publiczna powinna gwarantować społeczeństwu niezbędne minimum dóbr i usług publicznych ${ }^{66}$, zwłaszcza te o szczególnym znaczeniu społecznym. „Chodzenie do szkoły jest zaspokajaniem potrzeby edukacji, a zarazem korzystaniem z rzeczy użytku publicznego. Szkoły są zaliczane do kategorii rzeczy użytku publicznego, a równocześnie są środkiem do zaspokajania potrzeb edukacyjnych"67. Państwo, kierując się dobrem dzieci i młodzieży z niepełnosprawnością, stworzyło poprzez gwarancje prawne warunki do integracji ze społeczeństwem i ułatwienia w celu zdobycia wykształcenia i urealnienia prawa do nauki68.

Edukacja zgodnie z definicją słownikową postrzegana jest jako spójny system kształcenia i wychowania dzieci, młodzieży i dorosłych, obejmujący różne poziomy kształcenia, w formach instytucjonalnych i pozainstytucjonalnych ${ }^{69}$. Organizacja kształcenia, wychowania i opieki opiera się na zakresie podmiotowym, o którym mowa w art. 2 u.s.o., obejmując wymienione w nim typy i rodzaje szkół i placówek. Edukacja jest tą dziedziną społeczną, a szkoła instytucją społeczną ${ }^{70}$, która powinna przyczyniać się do włączenia osób z niepełnosprawnością do społeczności szkolnej i do codziennego życia w społeczeństwie. Dzieci i młodzież niepełnosprawne, niedostosowane społecznie i zagrożone niedostosowaniem społecznym, o których mowa w art. 1 pkt 5 u.s.o. ${ }^{71}$ i art. $71 \mathrm{~b}$ u.s.o. ${ }^{72}$, mają określone

pojęciami prawnymi i stanowią wartość motywacyjną działania administracji, wyznaczają granice dopuszczalnej ingerencji państwa (administracji publicznej) w sferę praw jednostki - ibidem, s. 19-20; zob. J. Supernat, Dobra publiczne i prawo administracyjne w dobie globalizacji, „Administracja. Teoria - Dydaktyka - Praktyka" 2011, nr 4, s. 152-153. Pojęcie dóbr publicznych, jak pisze J. Supernat, ,zawdzięczamy ekonomicznej analizie prawa, a wywodzi się ono z teorii ekonomii dobrobytu", ibidem, s. 151.

${ }^{65}$ Do takich wartości odwołują się m.in. redaktorzy w słowie wstępnym tomu Stan i kierunki rozwoju nauk administracyjnych, red. A. Błaś, J. Boć, Wrocław 2014, s. 7.

66 Zob. Administracja dóbr i ustug publicznych, red. M. Woźniak,Toruń 2013, s. 13.

${ }_{67}$ P. Chmielnicki, Świadczenie ustug przez samorzad..., s. 38; por. G. Szpor, op. cit., s. 141.

68 P. Bała, op. cit., Warszawa 2009, s. 447.

69 Mały słownik języka polskiego, Warszawa 1993.

70 Zob. M.J. Szymański, Socjologia edukacji. Zarys problematyki, Kraków 2013.

71 „System oświaty zapewnia w szczególności: możliwość pobierania nauki we wszystkich typach szkół przez dzieci i młodzież niepełnosprawną, niedostosowaną społecznie i zagrożoną niedostosowaniem społecznym, zgodnie $\mathrm{z}$ indywidualnymi potrzebami rozwojowymi i edukacyjnymi oraz predyspozycjami”.

72 „Kształceniem specjalnym obejmuje się dzieci i młodzież niepełnosprawne, niedostosowane społecznie i zagrożone niedostosowaniem społecznym, wymagające stosowania specjalnej organizacji nauki i metod pracy. Kształcenie to może być prowadzone w formie nauki odpowiednio w przedszkolach i szkołach ogólnodostępnych, przedszkolach i szkołach lub oddziałach integracyjnych, przedszkolach i szkołach lub oddziałach specjalnych, innych formach wychowania przedszkolnego i ośrodkach, o których mowa w art. 2 pkt 5". 
prawa i obowiązki wynikające z ustawy o systemie oświaty. Edukacja jest jedną z najważniejszych funkcji, jaką pełni szkoła ${ }^{73}$. „Szkoła winna zapewnić każdemu uczniowi warunki niezbędne do jego rozwoju, przygotować go do wypełniania obowiązków rodzinnych i obywatelskich w oparciu o zasady solidarności, demokracji, tolerancji, sprawiedliwości i wolności”74. Zdaniem J. Hrynkiewicz „szkoła pełni szczególną rolę w udostępnianiu dzieciom i młodzieży dóbr wiedzy i cywilizacji. Wpływa na kształtowanie aspiracji, ambicji i postaw. Uczestniczy w wyrównywaniu szans edukacyjnych lub pogłębianiu różnic społecznych" 75 . W literaturze nauk społecznych zauważa się m.in., że „współczesny system edukacji szkolnej nie wyrównuje szans, lecz sprzyja utrwaleniu i pogłębieniu zróżnicowania szans i możliwości rozwojowych dzieci i młodzieży"76. Trzeba mieć tu na uwadze i przyczyny, dla których część społeczeństwa może mieć trudniejszy dostęp do wykształcenia. Bariery te mogą mieć charakter psychologiczny — związane ze zdolnościami i predyspozycjami jednostek, przyczyny ekonomiczne — problemy finansowe poszczególnych rodzin, kwestie ekonomiczne na poziomie organizacji i zarządzania oświatą oraz społeczne — związane ze strukturą społeczną ${ }^{77}$. W przypadku osób niepełnosprawnych pojawiają się też inne bariery w edukacji. Dorota Kornas-Biela zauważa, że

przyczyn barier w edukacji niepełnosprawnych należy szukać nie tyle w ich ograniczonych możliwościach, ile raczej w postawach osób pełnosprawnych wobec nich. [...] Pokonanie przez osoby pełnosprawne barier wewnętrznych, które utrudniają kontakt z osobami odbiegającymi od normy umysłowej, stwarza szanse na większe możliwości edukacyjne każdemu członkowi tej interakcji (zatarty zostaje podział na „my” i ,oni”) ${ }^{78}$.

73 M.J. Szymański, Socjologia edukacji..., s. 137. Zdaniem M.J. Szymańskiego szkoła to „instytucja społeczna i organizacja formalna celowo tworzona do realizacji zadań wychowawczych, opiekuńczych i dydaktycznych uznanych za niezbędne do przygotowania dzieci, młodzieży i dorosłych do życia społecznego i pracy zawodowej. Ukierunkowana jest na przekaz treści nauczania, kształtowanie postaw i wartości zgodnie z przyjętymi programami kształcenia. Społecznie bardzo istotne jest też pozaprogramowe oddziaływanie społeczności szkolnej w ramach tak zwanego ukrytego programu. Formalne i pozaformalne wpływy szkoły na uczniów lub studentów, rodziców, otaczające ją środowisko czynią z niej jedną z ważniejszych agend socjalizacyjnych społeczeństwa".

74 Preambuła u.s.o.

75 J. Hrynkiewicz, Prawo dziecka do godziwych warunków socjalnych, [w:] Prawa dziecka..., s. $67-68$.

76 Ibidem, s. 68; zob. też Nierówność szans edukacyjnych..., red. W. Żłobicki, B. Maj, Kraków 2012.

77 Zob. M. Ślusarczyk, Prawo do nauki a nierówności edukacyjne, [w:] Jednostka w demokratycznym państwie prawa, red. J. Filipek, Bielsko-Biała 2003, s. 672-674; por. B. Maj, Nierówność szans edukacyjnych środowisk zróżnicowanych społecznie, [w:] Nierówność szans edukacyjnych..., s. 173-191; I. Paszenda, Nierówność dostępu do edukacji w szkole wyższej. Wybrane tendencje i egzemplifikacje, [w:] Nierówność szans edukacyjnych..., s. 229-247.

78 D. Kornas-Biela, Przekraczanie barier edukacyjnych w ujęciu pedagogiki niepetnosprawności Jeana Vaniera: inspiracje biograficzne, [w:] Nierówność szans edukacyjnych..., s. 379. 
Edukacja stanowi płaszczyznę nieustannego ścierania się różnorodnych presji politycznych, kulturowych i społeczno-ekonomicznych ${ }^{79}$. Kwestia nierówności szans edukacyjnych była i jest obecna w każdej polityce oświatowej państwa ${ }^{80}$. Pojawiające się utrudnienia i bariery w sferze usług oświatowych obejmują m.in. zakłócenia $\mathrm{w}$ dostępie do edukacji oraz nierówność udziału w niej środowisk miejskich, wiejskich i osób niepełnosprawnych ${ }^{81}$. Przyczyny nierówności szans edukacyjnych, ich skutki oraz koncepcje zmian w tym zakresie, są przedmiotem zwłaszcza nauk społecznych ${ }^{82}$. Powstaje pytanie, w jaki sposób na „starcie” edukacji państwo, i jego administracja publiczna, próbuje stworzyć równe szanse edukacyjne w zakresie prawa do nauki? Czy edukacja dzieci i młodzieży w XXI wieku oparta o wiele postulatów, programy edukacyjne, uczy współżycia w społeczeństwie, kształtuje zdolność do współdziałania, dialogu, tolerancji, szacunku dla środowiska naturalnego i kulturalnego, uczy samodzielności myślenia, niezależności sądów oraz otwarcia się i szacunku na wszelką inność ${ }^{83}$, np. bycie osobą niepełnosprawną? Czy są to może jedynie postulaty przewartościowania pojęcia edukacji ${ }^{84}$, prawne zmiany statusu szkoły, nieznajdujące odzwierciedlenia w rzeczywistości szkolnej?

Niewątpliwie, każde dziecko, bez względu na to czy jest w pełni sprawne, czy z niepełnosprawnością, ma prawo do nauki, o którym statuuje art. 70 Konstytucji RP, i prawo do korzystania z oświaty jako dobra wspólnego. „Szkoła powinna być nastawiona na taki rozwój dziecka, który ułatwi mu funkcjonowanie w społeczeństwie, rozumne funkcjonowanie jako obywatela i dobre funkcjonowanie

79 Zob. T. Gmerek, Edukacja i nierówności społeczne. Studium porównawcze na przykładzie Anglii, Hiszpanii i Rosji, Kraków 2011, s. 9 n.; B. Śliwerski, Problemy współczesnej edukacji. Dekonstrukcja polityki oświatowej w III RP, Warszawa 2009; idem, Edukacja (w)polityce. ...

80 M. Ślusarczyk, op. cit., s. 675-679.

81 Nierówność szans edukacyjnych..., s. 9. Z perspektywy socjologii edukacji, ważnymi barierami systemu edukacji w Polsce i w wielu innych krajach europejskich są: „nierówność udziału przedstawicieli poszczególnych grup społecznych w szkołach różnego typu i szczebla; nierówność startu edukacyjnego, która wynika z ekonomicznej, społecznej lub kulturowej odmienności warunków życia i rozwoju dzieci i młodzieży; nierówność szans, która wynika z odmiennych potrzeb, marzeń, dążeń i aspiracji żywionych przez młodzież, niezależnie od stopnia jej zdolności i ich realności, ale w zależności od miejsca zamieszkania lub przynależności do grupy społecznej; nierówność wykorzystania potencjału intelektualnego, która jest związana z zaniedbywaniem rozwoju dzieci szczególnie uzdolnionych przez szkołę i środowisko rodzinne", ibidem, s. 9; zob. B. Śliwerski, Demokracja w szkole — szkoła wyrównywania szans rozwojowych i edukacyjnych uczniów, [w:] Nierówność szans edukacyjnych..., s. 20.

82 Zob. Nierówność szans edukacyjnych...

83 Zob. Edukacja wobec wyzwań XXI wieku, red. I. Wojnar, J. Kubin, Warszawa 1996, s. 138.

${ }^{84}$ Szerzej zob. M. Kozak, op. cit., s. 24-25. M. Kozak pisze, że naczelnym zadaniem edukacji we współczesnym świecie, co wynika z międzynarodowych raportów edukacyjnych, „staje się przygotowanie każdej jednostki do twórczego uczestnictwa w kulturze i cywilizacji, a także do jej doskonalenia i rozwoju. Ta kreatywna rola jednostki wobec świata zewnętrznego obejmuje też świat wartości i stosunków międzyludzkich”, ibidem, s. 25. 
jako pracownika" 85 . Na władzach publicznych spoczywa obowiązek zapewnienia obywatelom powszechnego i równego dostępu do edukacji. Jak podkreśla Trybunał Konstytucyjny w wyroku z dnia 16 stycznia 2007 r. (U 5/06, Dz.U. Nr 10, poz. 70), powszechność i równość kształcenia rozumiana musi być jako równość szans $^{86}$. Zagadnienie równości w dostępie do edukacji — „termin ten wiąże się z brakiem jakichkolwiek barier formalnoprawnych, organizacyjnych czy finansowych na drodze dziecka i młodego człowieka do określonej instytucji edukacyjnej" ${ }^{87}$. Z kolei

powszechny dostęp do bezpłatnej edukacji wzbogaca każde społeczeństwo o wiedzę, doświadczenie i relacje społeczne, których rozwój i pomnażanie przyczynia się do podnoszenia jakości życia w wielu obszarach. Nowoczesne społeczeństwo, to społeczeństwo [...] dobrze wyedukowane, otwarte na wartości kultur Europy i świata ${ }^{88}$.

Prawo do nauki w kontekście dostępu do szkoły publicznej dzieci i młodzieży z niepełnosprawnością oraz wskazanie na prawne jej gwarancje w zakresie kształcenia specjalnego $\mathrm{w}$ obliczu zmian w prawie oświatowym to zagadnienie o charakterze interdyscyplinarnym, ciągle aktualne, nie tylko w ujęciu nauk prawnych. Jednkaże to właśnie na tle regulacji prawnych powstaje pytanie, jakie instrumenty administracyjnoprawne wprowadza ustawodawca do polskiego systemu oświaty, by zagwarantować osobom niepełnosprawnym realizację podmiotowego prawa do nauki w odpowiednio zorganizowanych i dostosowanych warunkach, o których stanowi ustawa o systemie oświaty.

\section{W KWESTII PODSTAW PRAWNYCH DOSTĘPU OSÓB NIEPEŁNOSPRAWNYCH DO EDUKACJI}

„Włączanie uczniów z niepełnosprawnością do szkolnej społeczności jest procesem, nie odbywa się przez sam fakt przebywania takiego dziecka w szkole czy przedszkolu. Proces ten wymaga zaangażowania się wielu podmiotów — organu prowadzącego, dyrektora, nauczycieli, poradni psychologiczno-pedagogicznej, rodziców i innych lokalnych instytucji - w zapewnienie dzieciom z niepełnosprawnością odpowiednich warunków kształcenia i form wsparcia"89. Jak pisze B. Marcinkowska: ,uczeń z niepełnosprawnością to ten, który ma orzeczenie o potrzebie kształcenia specjalnego, który z uwagi na zaburzenia i odchylenia rozwojowe o zróżnicowanej etiologii wymaga zastosowania specjalnej, indywidualnie dostoso-

85 A. Satel, Szkoła stużyć ma dziecku, „Dyrektor Szkoły” 2014, nr 1, s. 84.

86 Zob. D. Kurzyna-Chmiel, op. cit., s. 47-57.

87 I. Paszenda, op. cit., s. 234; por. J. Lackowski, Decentralizacja zarządzania polskim systemem oświatowym a społeczne nierówności edukacyjne, Kraków 2008, s. 27.

${ }^{88}$ E. Pierzchała, J. Pierzchała, op. cit., s. 111.

89 Dziecko z niepetnosprawnościa w przedszkolu i szkole ogólnodostępnej - wyzwania dla jst, red. A. Grabowska, Warszawa 2015, s. 3. 
wanej organizacji procesu edukacyjnego. Uczniowie z niepełnosprawnością mogą realizować obowiązek szkolny w szkołach ogólnodostępnych, szkołach lub oddziałach integracyjnych, szkołach lub oddziałach specjalnych oraz ośrodkach szkolno-wychowawczych” "90 „O wyborze szkoły dla dziecka decydują rodzice/prawni opiekunowie. Nie zawsze placówka ogólnodostępna jest w stanie zapewnić odpowiednie dla każdego dziecka warunki rozwoju, szczególnie dla dzieci z niepełnosprawnością sprzężoną. Jednak zdecydowana większość dzieci z niepełnosprawnością i deficytami rozwoju może i powinna realizować obowiązek szkolny w szkole najbliższej miejsca zamieszkania. Dla szkół ogólnodostępnych to zadanie nie jest łatwe, ponieważ każde niepełnosprawne dziecko jest wyzwaniem dla szkoły"91.

W deklaracji z Salamanki (UNESCO 1994, s. VIII) określono:

Każde dziecko ma fundamentalne prawo do nauki i należy dać mu szansę osiągnięcia i utrzymania odpowiedniego poziomu kształcenia; każde dziecko ma charakterystyczne indywidualne cechy, zainteresowania, zdolności i potrzeby w zakresie nauczania; systemy oświaty powinny być tworzone, a programy edukacyjne wdrażane $\mathrm{z}$ uwzględnieniem dużego zróżnicowania tych charakterystycznych cech i potrzeb; dzieci o specjalnych potrzebach edukacyjnych muszą mieć dostęp do zwykłych szkół, które powinny przyjąć je w ramach nauczania, które stawia w centrum zainteresowania dziecko i zdolne jest zaspokoić jego potrzeby; zwykłe szkoły o tak otwartej orientacji są najskuteczniejszym środkiem zwalczania dyskryminacji, tworzenia przyjaznych społeczności, budowania otwartego społeczeństwa oraz wprowadzania w życie edukacji dla wszystkich, co więcej, zapewniają one odpowiednie wykształcenie większości dzieci oraz poprawiają skuteczność, a także efektywność kosztową całego systemu oświaty ${ }^{92}$.

„W obowiązującym obecnie systemie prawnym zawarte są nie tylko przepisy formalne dotyczące litery prawa, ale także regulacje o charakterze merytorycznym (np. preferowane w danym kraju wartości , programy działań i ich cel)"93. $\mathrm{Z}$ art. 70 ust. 1 i 4 Konstytucji RP wynika, że „Każdy ma prawo do nauki [...]. Władze publiczne zapewniają obywatelom powszechny i równy dostęp do wykształcenia [...]". Polskie prawo oświatowe statuuje warunki do kształcenia, wychowania i opieki, odpowiednio do wieku i osiągniętego rozwoju. Ustawa o systemie oświaty zapewnia możliwość pobierania nauki we wszystkich typach szkół przez dzieci i młodzież niepełnosprawną zgodnie z indywidualnymi potrzebami rozwojowymi i edukacyjnymi oraz predyspozycjami. „System oświaty zapewnia w szczególności: [...] możliwość pobierania nauki we wszystkich typach szkół przez dzieci i młodzież niepełnosprawną oraz niedostosowaną społecznie, zgodnie z indywidualnymi potrzebami rozwojowymi i edukacyjnymi oraz predyspozycjami, a także opiekę nad uczniami niepełnosprawnymi przez umożliwianie realizowania zindywidualizowanego procesu kształcenia, form i programów nauczania

90 B. Marcinkowska, Ksztatcenie specjalne..., s. 128.

91 Dziecko z niepetnosprawnościa ..., red. A. Grabowska, s. 4.

92 B. Marcinkowska, Kształcenie specjalne w szkole ogólnodostępnej, [w:] Wsparcie dziecka z niepetnosprawnościa $w$ rodzinie i szkole..., red. D. Gorajewska, s. 125.

93 Prawo oświatowe..., s. 185. 
oraz zajęć rewalidacyjnych [...]"94. Szkoły i placówki wspierające rozwój dzieci powinny gwarantować im szanse edukacyjne, tak aby mogły one w pełni wykorzystać swoje możliwości psychofizyczne i osiągnąć wyniki zgodne z potencjałem rozwojowym ${ }^{95}$. Przypomnijmy, że w 2012 r. Polska ratyfikowała Konwencję ONZ o prawach osób niepełnosprawnych i tym samym zadeklarowała, że celem polityki oświatowej państwa jest wprowadzenie włączającego modelu kształcenia.

Jak wynika z art. 24 Konwencji ONZ o prawach osób niepełnosprawnych,

Państwa-Strony uznają prawo osób niepełnosprawnych do edukacji. W celu realizacji tego prawa bez dyskryminacji i na zasadach równych szans Państwa-Strony zapewnią włączający system kształcenia umożliwiający integrację na wszystkich poziomach edukacji i w kształceniu ustawicznym [...]. Aby wesprzeć realizację tego prawa, Państwa-Strony podejmą odpowiednie środki w celu zatrudniania nauczycieli, w tym nauczycieli niepełnosprawnych, którzy mają kwalifikacje w zakresie używania języka migowego i /lub alfabetu Braille'a, oraz w celu szkolenia specjalistów i personelu pracujących na wszystkich szczeblach edukacji. Takie szkolenie będzie obejmować wiedzę na temat problemów niepełnosprawności i korzystanie ze wspomagających (augmentatywnych) i alternatywnych sposobów, środków i form komunikacji, technik i materiałów edukacyjnych, w celu wspierania osób niepełnosprawnych. Państwa-Strony zapewnią, że osoby niepełnosprawne będą miały dostęp do powszechnego szkolnictwa wyższego, szkolenia zawodowego, kształcenia dorosłych i kształcenia ustawicznego, bez dyskryminacji i na zasadzie równości z innymi osobami. W tym celu Państwa-Strony zapewnią, że zapewnione będą racjonalne usprawnienia dla osób niepełnosprawnych ${ }^{96}$.

Państwa-Strony uznają, że dziecko psychicznie lub fizycznie niepełnosprawne powinno mieć zapewnioną pełnię normalnego życia w warunkach gwarantujących mu godność, umożliwiających osiągnięcie niezależności oraz ułatwiających aktywne uczestnictwo dziecka w życiu społeczeństwa. Państwa-Strony uznają prawo dziecka niepełnosprawnego do szczególnej troski i będą sprzyjały oraz zapewniały, stosownie do dostępnych środków, rozszerzanie pomocy udzielanej uprawnionym do niej dzieciom oraz osobom odpowiedzialnym za opiekę nad nimi. Pomoc taka będzie udzielana na wniosek tych osób i będzie stosowna do warunków dziecka oraz sytuacji rodziców lub innych osób, które się nim opiekują. Uznając szczególne potrzeby dziecka niepełnosprawnego, pomoc [...] będzie udzielana bezpłatnie tam, gdzie jest to możliwe, z uwzględnieniem zasobów finansowych rodziców bądź innych osób opiekujących się dzieckiem, i ma zapewnić, aby niepełnosprawne dziecko posiadało skuteczny dostęp do oświaty, nauki, opieki zdrowotnej, opieki rehabilitacyjnej, przygotowania zawodowego oraz możliwości rekreacyjnych, realizowany w sposób prowadzący do osiągnięcia przez dziecko jak najwyższego stopnia zintegrowania ze społeczeństwem oraz osobistego rozwoju, w tym jego rozwoju kulturalnego i duchowego ${ }^{97}$.

Podkreślmy, że prawa dzieci niepełnosprawnych w szczególny sposób są chronione w Konwencji o prawach dziecka ${ }^{98}$. Prawa dzieci i młodzieży z niepeł-

94 Art. 1 pkt 5 i 5 a u.s.o.

95 Dziecko z niepetnosprawnością..., s. 9.

96 Zob. Zasada równego traktowania, s. 5-6; Równe szanse w dostępie do edukacji osób z niepetnosprawnościami. Analiza i zalecenia, red. S. Trociuk, Biuletyn RPO, nr 7, Warszawa 2012. Raport przygotowany w ramach prac Komisji Ekspertów ds. Osób z Niepełnosprawnościami przy Rzeczniku Praw Obywatelskich (www.rpo.gov.pl).

97 Art. 23 Konwencji ONZ o prawach dziecka.

98 Zob. Konwencja o Prawach Dziecka. Analiza ...; E. Tokarczyk, Prawo dziecka do uzyskania wyksztatcenia, [w:] ibidem, s. 283-285; M. Andrzejewski, E. Tokarczyk, Prawa dzieci niepelnosprawnych, [w:] ibidem, s. 327-345. 
nosprawnościami określone są również w Konwencji ONZ o prawach osób niepełnosprawnych ${ }^{99}$, ratyfikowanej przez Polskę w 2012 r. W porządku wewnętrznym krajowym prawa osób z niepełnosprawnością w edukacji określa Konstytucja RP, ustawa o systemie oświaty, jak również uchwała Sejmu Rzeczypospolitej Polskiej z dnia 1 sierpnia 1997 r. Karta praw osób niepełnosprawnych ${ }^{100}$. Sejm RP w zakresie edukacji na rzecz osób z niepełnosprawnością określa w niniejszej Karcie w $§ 1$ pkt 4, że osoby te mają prawo do „nauki w szkołach wspólnie ze swymi pełnoprawnymi rówieśnikami, jak również do korzystania ze szkolnictwa specjalnego lub edukacji indywidualnej”. Prawa osób niepełnosprawnych statuowane w Karcie praw osób niepełnosprawnych, jak określa § 2 Karty, wynikają z „Konstytucji, Powszechnej Deklaracji Praw Człowieka, Konwencji Praw Dziecka, Standardowych Zasad Wyrównywania Szans Osób Niepełnosprawnych, aktów prawa międzynarodowego i wewnętrznego”, Sejm RP „wzywa rząd Rzeczypospolitej Polskiej i władze samorządowe do podjęcia działań ukierunkowanych na urzeczywistnienie tych praw".

Konwencja ONZ o prawach osób niepełnosprawnych ${ }^{101}$ (w skrócie „Konwencja”) jest ,pierwszym międzynarodowym aktem prawnym o zasięgu światowym, który w sposób całościowy odnosi się do sytuacji osób z niepełnosprawnościami w obszarze praw i wolności człowieka. Zasadniczym celem Konwencji jest popieranie, ochrona i zapewnienie pełnego i równego korzystania ze wszystkich praw człowieka i podstawowych wolności przez osoby z niepełnosprawnościami oraz poszanowanie ich przyrodzonej godności”. Jak wynika z art. 1 zd. 2 Konwencji, „Do osób niepełnosprawnych zalicza się te osoby, które mają długotrwale naruszoną sprawność fizyczną i umysłową, intelektualną lub w zakresie zmysłów co może, w oddziaływaniu z różnymi barierami, utrudniać im pełny i skuteczny udział w życiu społecznym, na zasadzie równości z innymi osobami”. W katalogu zasad ogólnych określonych w art. 3 Konwencji wymienić należy następujące zasady: 1) poszanowanie przyrodzonej godności, autonomii osoby, w tym swobody dokonywania wyborów, a także poszanowanie niezależności osoby; 2) niedyskryminacja; 3) pełny i skuteczny udział w społeczeństwie i integracja społeczna; 4) po-

99 Konwencja ONZ o prawach osób niepełnosprawnych przyjęta została przez Zgromadzenie Ogólne Narodów Zjednoczonych w dniu 13 grudnia 2006 r., A /RES/61/106, rząd Polski podpisał ją dnia 20 marca 2007 r., natomiast ratyfikacja Konwencji przez Polskę miała miejsce w dniu 6 września 2012 r. (Dz.U. z 2012 r. poz. 1169). „Celem Konwencji jest ochrona i zapewnienie pełnego i równego korzystania z praw człowieka i podstawowych wolności przez osoby z niepełnosprawnościami na równi ze wszystkimi innymi obywatelami. Polska zobowiązana jest do wprowadzenia w życie zawartych w Konwencji standardów postępowania w celu zapewnienia osobom z niepełnosprawnościami realizacji ich praw" (https://www.rpo.gov.pl/pl/konwencja-o -prawach-osob-niepełnosprawnych), (dostęp: 10 listopada 2015).

100 M.P. nr 50, poz. 475.

101 Konwencja o prawach osób niepetnosprawnych. Poradnik RPO, red. S. Trociuk, Biuletyn RPO-Materiały nr 82, Biuro RPO, Warszawa 2013, s. 5, https://www.rpo.gov.pl (dostęp: 16 grudnia 2015). 
szanowanie odmienności i akceptacja osób niepełnosprawnych, będących częścią ludzkiej różnorodności oraz ludzkości; 5) równość szans; 6) dostępność; 7) równość mężczyzn i kobiet; 8) poszanowanie rozwijających się zdolności niepełnosprawnych dzieci oraz poszanowanie prawa dzieci niepełnosprawnych do zachowania tożsamości.

\section{Jak statuuje art. 9 Konwencji:}

by zapewnić samodzielne życie i pełny udział w życiu społecznym osobom z niepełnosprawnościami, państwo powinno umożliwić wszystkim równy dostęp do obiektów i usług powszechnie oferowanych. Chodzi tu m.in. o dostęp do transportu, informacji, komunikacji, a także innych powszechnie oferowanych usług. Dotyczy to także dostępu do budynków, dróg, środków transportu, szkół, szpitali czy miejsc pracy ${ }^{102}$.

Konwencja zakłada, że „,bariery napotykane przez osoby z niepełnosprawnościami w dużej mierze są skutkiem złej organizacji przestrzeni lub nieodpowiedniego nastawienia ludzi i instytucji. Takie ujęcie niepełnosprawności podkreśla, że osoby z niepełnosprawnościami mają równe prawa z innymi i są lub mogą być aktywnymi członkami społeczności, a nie jedynie odbiorcami wsparcia, opieki społecznej czy biernym przedmiotem decyzji innych osób"103. Konwencja zapewnia „ochronę praw i godności osób z niepełnosprawnościami, a także promuje ich aktywny udział we wszystkich sferach życia: obywatelskiej, politycznej, gospodarczej, społecznej i kulturalnej. Konwencja podkreśla też potrzebę zagwarantowania samodzielności i niezależności osobom z niepełnosprawnościami”104.

\section{$\mathrm{Z}$ art. 24 Konwencji w zakresie edukacji wynika, że}

tak samo jak wszyscy i bez jakiejkolwiek formy dyskryminacji osoby z niepełnosprawnościami mają prawo do edukacji. Państwa powinny zagwarantować: dostęp do systemu edukacji włączającej na wszystkich etapach kształcenia oraz do kształcenia ustawicznego, tak aby zapewnić osobom z niepełnosprawnościami pełny rozwój ich możliwości i udział w społeczeństwie, równy z innymi dostęp do bezpłatnej i obowiązkowej edukacji, w tym edukacji włączającej na poziomie podstawowym i średnim, stosowanie racjonalnego dostosowania na wszystkich etapach edukacji, wsparcie uczniów i instytucji edukacyjnych umożliwiające efektywne kształcenie, dostosowane do indywidualnych, szczególnych potrzeb osób z niepełnosprawnościami, naukę umiejętności życiowych i społecznych, które ułatwią osobom z niepełnosprawnościami uczestnictwo w edukacji i życiu społecznym, na przykład poprzez naukę alfabetu Braille'a , pisma alternatywnego, orientacji przestrzennej czy języka migowego, dostęp do szkolnictwa wyższego, zawodowego, edukacji dorosłych i kształcenia ustawicznego, bez dyskryminacji i na równych zasadach z innymi obywatelami ${ }^{105}$.

Z przepisów ustawy o systemie oświaty i aktów normatywnych wydawanych przez ministra MEN, jak również z porządku prawnego określającego politykę

\footnotetext{
102 Ibidem, s. 6.

103 Ibidem.

104 Ibidem.

105 Ibidem, s. 8
} 
społeczną, w tym kompetencje j.s.t. i podmiotów administracji publicznej106, wynika, że kształcenie specjalne jest integralną częścią systemu oświaty ${ }^{107}$. Prawo do nauki gwarantuje zarówno Konstytucja RP, jak i ustawa o systemie oświaty. Przepisy u.s.o. oraz rozporządzeń wykonawczych do niej umożliwiają organizację kształcenia, wychowania i opieki dzieci i młodzieży z niepełnosprawnościami w formach zapewniających im realizację obowiązku rocznego przygotowania przedszkolnego, obowiązku szkolnego i obowiązku nauki. Rozporządzenie MEN z dnia 24 lipca 2015 r. w sprawie warunków organizowania kształcenia, wychowania i opieki dla dzieci i młodzieży niepełnosprawnych, niedostosowanych społecznie i zagrożonych niedostosowaniem społecznym (Dz.U. poz. 1113) stanowi wykonanie upoważnienia zawartego $\mathrm{w}$ art. $71 \mathrm{~b}$ ust. 7 pkt 2 ustawy z dnia 7 września 1991 r. o systemie oświaty (Dz.U. z 2004 r. Nr 256, poz. 2572, z późn. zm.), w brzmieniu nadanym przez art. 1 pkt 51 lit. d ustawy z dnia 20 lutego 2015 r. o zmianie ustawy o systemie oświaty oraz niektórych innych ustaw (Dz.U. poz. 357). Rozporządzenie MEN z dnia 24 lipca 2015 r. ${ }^{108}$ określa warunki organizowania kształcenia, wychowania i opieki dla dzieci i młodzieży: 1) niepełnosprawnych: niesłyszących, słabosłyszących, niewidomych, słabowidzących, $\mathrm{z}$ niepełnosprawnością ruchową, $\mathrm{w}$ tym $\mathrm{z}$ afazją, $\mathrm{z}$ niepełnosprawnością intelektualną w stopniu lekkim, umiarkowanym lub znacznym, z autyzmem, w tym z zespołem Aspergera, i z niepełnosprawnościami sprzężonymi, zwanych „uczniami niepełnosprawnymi”; 2) niedostosowanych społecznie; 3) zagrożonych niedostosowaniem społecznym - wymagających stosowania specjalnej organizacji nauki i metod pracy. Zgodnie z $§ 2$ ust. 1 niniejszego rozporządzenia:

Kształcenie, wychowanie i opiekę dla uczniów niepełnosprawnych organizuje się w: 1) przedszkolach ogólnodostępnych; 2) przedszkolach ogólnodostępnych z oddziałami integracyjnymi; 3) przedszkolach integracyjnych; 4) przedszkolach ogólnodostępnych z oddziałami specjalnymi; 5) przedszkolach specjalnych; 6) innych formach wychowania przedszkolnego; 7) szkołach ogólnodostępnych; 8) szkołach ogólnodostępnych z oddziałami integracyjnymi; 9) szkołach integracyjnych; 10) szkołach ogólnodostępnych z oddziałami specjalnymi; 11) szkołach specjalnych, w tym szko-

106 Zob. Samorzady i administracja rządowa na rzecz osób niepetnosprawnych. Zbiór przepisów prawnych dotyczacych uprawnień dzieci i młodzieży niepetnosprawnych i ich rodzin, red. B. Winczewska, Warszawa 2013, s. 49 n.

107 Prawo oświatowe..., s. 185-197.

108 Niniejsze rozporządzenie było poprzedzone rozporządzeniem Ministra Edukacji Narodowej z dnia 17 listopada 2010 r. w sprawie warunków organizowania kształcenia, wychowania i opieki dla dzieci i młodzieży niepełnosprawnych oraz niedostosowanych społecznie w specjalnych przedszkolach, szkołach i oddziałach oraz w ośrodkach (Dz.U. z 2014 r. poz. 392) oraz rozporządzeniem Ministra Edukacji Narodowej z dnia 17 listopada 2010 r. w sprawie warunków organizowania kształcenia, wychowania i opieki dla dzieci i młodzieży niepełnosprawnych oraz niedostosowanych społecznie w przedszkolach, szkołach i oddziałach ogólnodostępnych lub integracyjnych (Dz.U. z 2014 r. poz. 414), które tracą moc z dniem 1 września 2015 r. w związku z wejściem w życie ustawy z dnia 20 lutego 2015 r. o zmianie ustawy o systemie oświaty oraz niektórych innych ustaw (Dz.U. poz. 357). Rozporządzenie MEN z 24 lipca 2015 r. wchodzi w życie z dniem 1 września 2015 r., z wyjątkiem $§ 7$ ust. 2-6, które wchodzą w życie z dniem 1 stycznia 2016 r. 
łach specjalnych przysposabiających do pracy; 12) młodzieżowych ośrodkach wychowawczych; 13) młodzieżowych ośrodkach socjoterapii; 14) specjalnych ośrodkach szkolno-wychowawczych; 15) specjalnych ośrodkach wychowawczych; 16) ośrodkach umożliwiających dzieciom i młodzieży $\mathrm{z}$ upośledzeniem umysłowym w stopniu głębokim, a także dzieciom i młodzieży z upośledzeniem umysłowym z niepełnosprawnościami sprzężonymi realizację odpowiednio obowiązku rocznego przygotowania przedszkolnego, obowiązku szkolnego i obowiązku nauki.

„Kształcenie, wychowanie i opiekę dla uczniów niepełnosprawnych w przedszkolach, innych formach wychowania przedszkolnego, szkołach i oddziałach, o których mowa w ust. 1 pkt 1-3 i 6-9, organizuje się na każdym etapie edukacyjnym, w integracji z uczniami pełnosprawnymi, w przedszkolu, innej formie wychowania przedszkolnego lub szkole, najbliższych miejsca zamieszkania ucznia niepełnosprawnego” (§ 2 ust. 2 rozporządzenia). „Przedszkoli specjalnych i oddziałów specjalnych w przedszkolach ogólnodostępnych nie organizuje się dla dzieci z niepełnosprawnością intelektualną w stopniu lekkim" (§ 2 ust. 3 rozporządzenia). „Szkoły specjalne przysposabiające do pracy organizuje się wyłącznie dla uczniów z niepełnosprawnością intelektualną w stopniu umiarkowanym lub znacznym oraz dla uczniów z niepełnosprawnościami sprzężonymi” (§ 2 ust. 4 rozporządzenia). „Kształcenie specjalne w ośrodkach, o których mowa w ust. 1 pkt 16, organizuje się dla dzieci i młodzieży z niepełnosprawnością intelektualną w stopniu lekkim, umiarkowanym lub znacznym z niepełnosprawnościami sprzężonymi” (§ 2 ust. 5 rozporządzenia). Jak wynika z § 4 rozporządzenia: „Kształcenie uczniów niepełnosprawnych, niedostosowanych społecznie i zagrożonych niedostosowaniem społecznym może być prowadzone do końca roku szkolnego w tym roku kalendarzowym, w którym uczeń kończy: 1) 18. rok życia w przypadku szkoły podstawowej; 2) 21. rok życia — w przypadku gimnazjum; 3) 24. rok życia — w przypadku szkoły ponadgimnazjalnej”.

$\mathrm{W}$ edukacji ucznia z niepełnosprawnością w ocenie B. Marcinkowskiej „ważne jest zapewnienie mu warunków skutecznego włączenia w środowisko rówieśnicze oraz w życie środowiska lokalnego. Ponieważ włączanie jest złożonym procesem społecznym, psychologicznym i pedagogicznym, wymaga aktywnego udziału zarówno ucznia z niepełnosprawnością, jak i jego sprawnych rówieśników, placówki edukacyjnej oraz domu rodzinnego i środowiska lokalnego" 109.

\section{WNIOSKI}

Zgodzić wypada się z K. Kaczmarkiem, który pisze: „Niepełnosprawność i uznanie kogoś za osobę z niepełnosprawnością w dużej mierze zależą od otoczenia”" ${ }^{110}$. Jak pisze autor: „otoczenie, które stawia przed osobą z niepełnosprawno-

109 B. Marcinkowska, op. cit., s. 130.

110 K. Kaczmarek, Z perspektywy dorosłego dziecka sprawnego w swej niepetnosprawności, [w:] Wsparcie dziecka z niepetnosprawnościa w rodzinie i szkole..., s. 11. 
ścią bariery architektoniczne, prawne, mentalne a przede wszystkim społeczne"111. Zdaniem tego autora, ,tylko wiedza na temat niepełnosprawności pozwala nie bać się kontaktu z osobami z niepełnosprawnością. [...] Szkoła jest ogromnym wsparciem zarówno dla dziecka, jak i dla jego rodziców. [...] Integracja jest najważniejszym, nieodzownym elementem współdziałania osób pełnosprawnych z niepełnosprawnością”112. „Dzieci i młodzież z niepełnosprawnościami oraz zagrożone niedostosowaniem społecznym i niedostosowane społecznie w systemie oświaty mają określone prawa. Na pomoc mogą liczyć rodzice tych dzieci. W przepisach oświatowych uczeń niepełnosprawny ma te same prawa, co jego pełnosprawny kolega, choć z racji swej niepełnosprawności ma być w pewnych aspektach dodatkowo wspomagany” "113. Jak pisze B. Maj, ,edukacja to dla współczesnego człowieka wartość autoteliczna oraz instrumentalna. [...] zakłada się, że powinna przygotować jednostkę do życia, pracy i aktywnego kształtowania rzeczywistości nie tylko dla siebie, ale także dla przyszłych pokoleń. Zadaniem państwa oraz podmiotów mających wpływ na jakość edukacji powinno być prowadzenie takiej polityki, aby żadna jednostka w tym procesie nie została pominięta" 114 .

W demokratycznym państwie prawa rola oświaty ukierunkowana jest na realizację zadania oświatowego o charakterze publicznym, uznanego za „dobro wspólne całego społeczeństwa", na których podstawie budowany jest europejski system wartości ${ }^{115}$. Oświata, $z$ uwagi na jej znaczenie społeczne, znajduje się wśród dóbr niematerialnych, których świadczenie wiąże się z zadaniami oświatowymi wykonywanych przez państwo i samorząd terytorialny ${ }^{116}$. Należy w tym miejscu zauważyć, że „W państwie prawa jest to zawsze jakaś kategoria obowiązkowej aktywności organów państwa prawa. Państwo i jego organy nie korzystają w wykonywaniu zadań publicznych z jakichś swoich uprawnień, lecz wykonują zawsze obowiązki” 117 . Zdaniem Adama Błasia „Konstytucyjne określenie obowiązków państwa staje się podstawą do ustawowego określania zadań publicznych dla ad-

111 Ibidem.

112 Ibidem, s. 13. „Integracja powinna polegać [...] na przenikaniu się wszystkich sfer życia obu grup do tego stopnia, aż stworzą jedno niczym nieograniczone społeczeństwo. Powinniśmy wspólnymi siłami niwelować i likwidować wszystkie bariery, jakie stoją na drodze integracji”, s. $15,17$.

113 Samorządy i administracja rządowa na rzecz osób niepetnosprawnych, red. B. Winczewska, s. 50 .

114 B. Maj, op. cit., s. 190-191.

115 Zob. E. Pierzchała, J. Pierzchała, op. cit., s. 111.

116 Zob. R. Raszewska-Skałecka, Wybrane problemy administracji świadczacej w zakresie wykonywania zadań oświatowych przez jednostki samorządu terytorialnego, „Przegląd Prawa i Administracji” 2015, nr 100, tj. t. C/1, s. 127-148; eadem, Decentralizacja zadań oświatowych w kontekście wyzwań i oczekiwań społecznych, [w:] Administracja publiczna wobec wyzwań i oczekiwań społecznych, red. M. Giełda, R. Raszewska-Skałecka, Wrocław 2015, s. 145-164 (http://www.bibliotekacyfrowa.pl/publication/73349)

117 A. Błaś, Jednostka wobec administracji publicznej w przeobrażajacym się państwie prawa, [w:] Jednostka w demokratycznym państwie prawa, red. J. Filipek, Bielsko-Biała 2003, s. 32. 
ministracji publicznej"118, np. prawo do nauki - obowiązki edukacyjne — zadania oświatowe - w tym kształcenie specjalne określone w drodze ustawy o systemie oświaty i ustaw ustrojowych jednostek samorządu terytorialnego. Zadania administracji publicznej „muszą współbrzmieć z konstytucyjnie chronionymi prawami i wolnościami obywateli" 119 , jak np. prawo do nauki. W demokratycznym państwie prawa, zadania administracji publicznej w zakresie oświaty określone są przepisami prawa powszechnie obowiązującego rangi konstytucyjnej i ustawowej. Podkreślić przy tym należy, że norma prawna gwarantująca prawo dostępu do powszechnej i bezpłatnej edukacji zawarta jest w Konstytucji RP. Świadczy to o roli i funkcji, jaką przypisuje się edukacji i konieczności zapewnienia przez państwo i jego organy prawnych gwarancji dostępu do niej. Określenie sposobów zapewnienia wykonywania przez administrację publiczną obowiązków edukacyjnych zastrzeżone zostało już jednak do materii ustawowej ${ }^{120}$.

W nauce prawa administracyjnego oświata „należy do tej kategorii dóbr świadczonych przez zakłady administracyjne, których pozyskanie jest nie tylko prawem, ale i obowiązkiem destynatariuszy. Obowiązkowy charakter mają tu zarówno powinności państwa, jak i jednostek. Obowiązki państwa i jego administracji wynikają nie tylko z ustawodawstwa krajowego, ale i z wielu aktów prawa międzynarodowego"121. Dodajmy, że postanowienia aktów międzynarodowych znajdują odzwierciedlenie w normach krajowego porządku prawnego. Zaspokojenie potrzeby wiedzy i zagwarantowanie powszechności dostępu do edukacji stanowić powinny obowiązek prawny państwa i samorządu terytorialnego ${ }^{122}$. Zaspokojenie niniejszych potrzeb w sposób trwały zagwarantowane jest przez nałożenie odpowiedzialności za realizację przedmiotowego zadania na administrację publiczną ${ }^{123}$. W państwie prawa zadania publiczne wykonywane przez organy administracji publicznej pojmowane są jako określone obowiązki prawne tych organów, wykonywane dla urzeczywistnienia praw podmiotowych obywateli, $w$ tym prawo podmiotowe do nauki ${ }^{124}$.

118 A. Błaś, Zadania administracji publicznej..., s. 144. Zdaniem autora „stanowi także gwarancję, że rząd nie może uwolnić się od przyjęcia na siebie zadań publicznych, które określi ustawodawca", ibidem.

119 Ibidem, s. 137.

120 Obywatel a obowiazek rocznego przygotowania przedszkolnego, obowiazek szkolny oraz obowiazek nauki, [w:] Prawo administracyjne, red. J. Boć, Wrocław 2007, s. 452.

121 P. Chmielnicki, Zaktady..., s. 163.

122 P. Chmielnicki, Świadczenie ustug przez samorząd terytorialny..., s. 38.

123 P. Chmielnicki, Zaktady..., s. 164.

124 A. Błaś, J. Boć, J. Jeżewski, Administracja publiczna, red. J. Boć, Wrocław 2003, s. 42; zob. W. Jakimowicz, Publiczne prawa podmiotowe, Kraków 2002. 


\title{
EDUCATION OF PEOPLE WITH DISABILITIES AS A COMMON GOOD - CONSIDERATIONS ON ADMINISTRATIVE AND LEGAL BACKGROUND
}

\begin{abstract}
Summary
Education of people with disabilities, considered as a common good, points out legal subjectivity of a disabled person, the right to education and educational duties in the educational system. From the perspective of the state and its administration education, understood as a common good, means performance of educational tasks in the scope of special education for a disabled person.
\end{abstract}

